$$
\begin{array}{r}
\text { DP-1601 } \\
\text { Distribution Category: UC-10 }
\end{array}
$$

\title{
HYDRAZINE REDUCTION OF Np(V) AND Pu(IV)
}

\author{
DP--1601
}

DE82 010816

D. G. KARRAKER

Approved by

H. D. Harmon, Research Manager Actinide Technology Division

Publication Date: November 1981

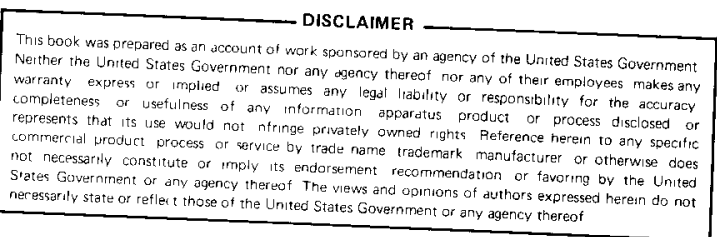

Neither the United States Government work sponsored by an agency of the United States Government: comany express or implied br assumes anny legal labuthy or or their empioyees makes any epresents that its use would not nfringesmation apparatus product or process disclosed or necessarly constirute or mente by irade name trademark manufacturer or otherwise does

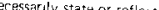
agency thereof

\section{E. 1. du Pont de Nemours \& Co. Savannah River Laboratory Aiken, SC 29808}

PREPARED FOR THE U. S. DEPARTMENT OF ENERGY UNDER CONTRACT DE-AC09-76SR00001 


\section{DISCLAIMER}

This report was prepared as an account of work sponsored by an agency of the United States Government. Neither the United States Government nor any agency Thereof, nor any of their employees, makes any warranty, express or implied, or assumes any legal liability or responsibility for the accuracy, completeness, or usefulness of any information, apparatus, product, or process disclosed, or represents that its use would not infringe privately owned rights. Reference herein to any specific commercial product, process, or service by trade name, trademark, manufacturer, or otherwise does not necessarily constitute or imply its endorsement, recommendation, or favoring by the United States Government or any agency thereof. The views and opinions of authors expressed herein do not necessarily state or reflect those of the United States Government or any agency thereof. 


\section{DISCLAIMER}

Portions of this document may be illegible in electronic image products. Images are produced from the best available original document. 
$\mathrm{Np}(\mathrm{V})$ and $\mathrm{Pu}(\mathrm{IV})$ in $8 \mathrm{M} \mathrm{HNO}_{3}$ were reduced by hydrazine at $50^{\circ} \mathrm{C}$ in $1 / 2$ to 2 hours. In $4 \mathrm{M}$ and $1.5 \mathrm{M} \mathrm{HNO}_{3}$, $\mathrm{Np}(\mathrm{V})$ reduction by hydrazine was more rapid and complete with a $\mathrm{Cu}($ II) or an $\mathrm{Fe}$ (III) ion catalyst. 
Introduction 5

Fxperimenta1 5

Neptunium 5

Plutonium 6

Results 7

Neptunium Reduction 7

Plutonium Reduction 10

Discussion 11 
$-4-$ 
HYDRAZINE REDUCTION OF Np(V) AND Pu(IV)

\section{INTRODUCTION}

The recovery and decontamination of neptunium by anion exchange and solvent extraction processes depend principally upon processing neptunium as the (IV) ion. Currently, $\mathrm{Np}(\mathrm{V})$, the natural Np valence in most process solutions, is reduced by ferrous sulfamate (FeSA) or FeSA-hydrazine nitrate solution. FeSA is a principal contributor to solids in the waste streams $\left[\mathrm{Fe}(\mathrm{OH})_{3}, \mathrm{Na}_{2} \mathrm{SO}_{4}\right]$, and increased corrosion of waste evaporators has been attributed to the sulfate produced by sulfamate decomposition. Thus, there is an economic incentive to reduce or to eliminate FeSA in plant processes.

Similarly, recovery and decontamination of plutonium depend upon control of its valence - Pu(IV) extracts into TBP, and is absorbed on anion exchange resin. In particular, the separation of $238 \mathrm{Pu}$ from ${ }^{237} \mathrm{~Np}$ in the anion exchange process depends upon the absorption of $\mathrm{Np}$ (IV) on the anion resin and the poor absorption of $\mathrm{Pu}(\mathrm{III})$. Control of the actinide valences is crucial to the success of this process. Presently, hydrazine nitrate and FeSA

are used in control of $\mathrm{Np}$ and $\mathrm{Pu}$ valences.

FeSA-hydrazine nitrate solutions are normally used at ambient temperatures (ca 28 to $33^{\circ} \mathrm{C}$ ). At these temperatures, hydrazine acts only as a holding reductian, protecting FeSA and other reduced species [Np(IV), Pu(III)] from nitrous acid-catalyzed oxidation. Hydrazine is a strong reducing agent, but high temperatures and metal-ion catalysts are often necessary to achieve acceptable reaction rates. This work explores the use of hydrazine to reduce $\mathrm{Np}(\mathrm{V})$ and $\mathrm{Np}(\mathrm{VI})$ to $\mathrm{Np}(\mathrm{IV})$ and $\mathrm{Pu}(\mathrm{IV})$ to $\mathrm{Pu}($ III).

\section{EXPERIMENTAL}

\section{Neptunium}

Solutions of the approximate concentration of plant neptunium solutions were prepared by mixing stock solutions of $0.83 \mathrm{M} \mathrm{N} \mathrm{N}_{2} \mathrm{H}_{4} \cdot \mathrm{HNO}_{3}, 0.22 \mathrm{M}(52.4 \mathrm{~g} / \mathrm{L}) \mathrm{Np}(\mathrm{V})$ in $2 \mathrm{M} \mathrm{HNO}_{3}, 10 \mathrm{M} \mathrm{HNO}_{3}$, $1 \mathrm{M} \mathrm{Cu}\left(\mathrm{NO}_{3}\right)_{2}$ and $2 \mathrm{M} \mathrm{Fe}\left(\mathrm{NO}_{3}\right)_{3}$. The test solutions were heated to $50^{\circ} \mathrm{C}$ for periods ranging from $1 / 2$ to 3 hours; then, the Np valence. 
and amount of each valence were determined by the absorption spectrum from 6000 to 13000 \& with a Cary 14 spectrophotometer. Blank solutions containing all reagents except $\mathrm{Np}$ were used as reference.

Determination of the valence from absorption spectra used the absorption maxima and molar absorptivities shown in Table 1.

TABLE 1

Np Valence Determination Spectra*

$\begin{array}{lll}\text { Np Valence } & \frac{\lambda \max , \AA}{\text { VI }} & \frac{\varepsilon_{m}(M-c m)}{}{ }^{-1} \\ \text { V } & 12,300 & 40 \\ & 9,800 & 230 \\ \text { IV } & 10,950 & 14 \\ & 7,000 & 50 \\ & 9,800 & 30\end{array}$

* 4M HNO 3 solution.

The molar absorptivities vary somewhat with nitric acid concentration and with the resolution of the spectrophotometer. The values chosen for $\mathrm{Np}(\mathrm{V})$ were determined in this work; other values come froin recent ORNL work. 1 An older SRL study ${ }^{2}$ showed little variation for the 7000 A peak of $\mathrm{Np}$ (IV) between 1 and $6 \mathrm{M} \mathrm{HNO}_{3}$, but the absolute values of that study were low because of the model spectrophotometer used. Because of the variation of molar absorptivities with nitric acid concentration and the interference between $\mathrm{Np}(V)$ and $\mathrm{Np}(\mathrm{IV})$ peaks at $9800 \AA$, small values for $\mathrm{Np}(\mathrm{V})$ species have considerable relative uncertainty.

\section{Plutonium}

Solutions for study were prepared by mixing a stock solution of $\mathrm{Pu}(\mathrm{IV})(49.83 \mathrm{~g} \mathrm{Pu} / \mathrm{L}, 0.208 \mathrm{M})$ with stock solutions of $10 \mathrm{M} \mathrm{HNO}_{3}$, $0.83 \mathrm{M} \mathrm{N}_{2} \mathrm{H}_{4} \cdot \mathrm{HNO}_{3}, 1 \mathrm{M} \mathrm{Cu}\left(\mathrm{NO}_{3}\right)_{2}, 2 \mathrm{M} \mathrm{Fe}\left(\mathrm{NO}_{3}\right)_{3}$ and $0.5 \mathrm{M} \mathrm{Na}{ }_{2} \mathrm{MoO}_{4}$. The test solutions were treated as described for $\mathrm{Np}$ studies, and the $\mathrm{Pu}$ valence resulting from the treatment determined spectrophotometrically from the absorbance of $\mathrm{Pu}(\mathrm{IV})$ at $4800 \AA$ and $\mathrm{Pu}$ (III) at $6000 \AA$. The molar absorptivities of $\mathrm{Pu}(\mathrm{IV})$ and $\mathrm{Pu}(\mathrm{III})$ determined in $8 \mathrm{M} \mathrm{HNO}_{3}$ are shown in Table 2 . 
TABLE 2

Pu Valence Determination Spectra

\begin{tabular}{|c|c|c|c|}
\hline \multirow[b]{2}{*}{ Pu Valence } & \multirow[b]{2}{*}{$\lambda \max , \AA$} & \multicolumn{2}{|c|}{$\varepsilon_{m}(M-c m)^{-1}$} \\
\hline & & $8 \mathrm{M} \mathrm{HNO}_{3}$ & $0.2 \mathrm{M} \mathrm{HClO}_{4}$ \\
\hline IV & $\begin{array}{l}4820 \\
6015\end{array}$ & $\begin{array}{l}47 \\
22\end{array}$ & $\begin{array}{l}56 \\
4\end{array}$ \\
\hline $\operatorname{III}$ & $\begin{array}{l}6015 \\
4820\end{array}$ & $\begin{array}{l}35 \\
3.5\end{array}$ & $\begin{array}{l}37 \\
3\end{array}$ \\
\hline
\end{tabular}

The values determined agree for $\mathrm{Pu}(\mathrm{III})$ in $0.2 \mathrm{M} \mathrm{HClO}_{4}$, (Reference 3), and the disagreement for $\mathrm{Pu}(I V)$ probably reflects spectral changes caused by strong nitrate complexing of $\mathrm{Pu}$ (IV). Corrections for the interference of $\mathrm{Pu}$ (IV) with $\mathrm{Pu}$ (III) spectra were applied to the data.

\section{RESULTS}

Neptunium Reduction

The reaction rate and reaction products of hydrazine oxidation are known 4,5 to depend upon acid concentration and reaction temperatures. Therefore, experiments were carried out at three different acid strengths, $1.5 \mathrm{M} \mathrm{HNO}_{3}, 4.16 \mathrm{M} \mathrm{HNO} 3$, and $7.92 \mathrm{M} \mathrm{HNO}$. Experiments in $1.5 \mathrm{M} \mathrm{HNO}_{3}$ are summarized in Table 3.

\section{TABLE 3}

$\mathrm{Np}$ (V) Reduction in $1.5 \mathrm{M} \mathrm{HNO}_{3} *$

\begin{tabular}{|c|c|c|c|c|}
\hline Catalyst & $\begin{array}{l}\text { Time, } \\
\mathrm{hr}\end{array}$ & $\begin{array}{l}\text { Temp, } \\
{ }^{\circ} \mathrm{C} \\
\end{array}$ & $\% \mathrm{~Np}(\mathrm{~V})$ & $\% \mathrm{~Np}$ (IV) \\
\hline None & 1 & 70 & $\sim 100$ & - \\
\hline $0.008 \mathrm{M} \mathrm{Cu}(\mathrm{II})$ & 1 & 70 & 20 & 80 \\
\hline $0.004 \mathrm{M} \mathrm{Cu}(\mathrm{II})$ & 2 & 50 & - & $\sim 100$ \\
\hline $0.008 \mathrm{M} \mathrm{Fe}($ III $)$ & 2 & 50 & - & $\sim 100$ \\
\hline $0.003 \mathrm{M} \mathrm{Fe}-0.004 \mathrm{M} \mathrm{Cu}(\mathrm{II})$ & 2 & 50 & - & $\sim 100$ \\
\hline
\end{tabular}

\footnotetext{
* Initial solution concentrations: $1.5 \mathrm{M} \mathrm{HNO}_{3}, 0.10 \mathrm{M} \mathrm{N} \mathrm{N}_{2} \mathrm{H}_{4}$, and $0.018 \mathrm{M} \mathrm{Np}(\mathrm{V})$.
} 
These results show that heating and catalytic amounts of either $\mathrm{Cu}(\mathrm{II})$ or $\mathrm{Fe}(\mathrm{III})$ lead to essentially complete reduction of $\mathrm{Np}(\mathrm{V})$ in $1.5 \mathrm{M} \mathrm{HNO}_{3}$.

In $4 \mathrm{M} \mathrm{HNO}_{3}$, the reduction of $\mathrm{Np}(\mathrm{V})$ was improved by $\mathrm{Fe}$ (III) catalyst, but Cu(II) had no catalytic effect at this acid concentration. The results are shown in Table 4.

TABLE 4

$\mathrm{Np}(\mathrm{V})$ Reduction in $4 \mathrm{M} \mathrm{HNO}_{3}$ *

\begin{tabular}{|c|c|c|c|c|}
\hline Catalyst & $\begin{array}{l}\text { Time, } \\
\mathrm{hr} \\
\end{array}$ & $\begin{array}{l}\text { Temp, } \\
{ }^{\circ} \mathrm{C} \\
\end{array}$ & $\% \mathrm{~Np}(\mathrm{~V})$ & $\% \mathrm{~Np}$ ( IV) \\
\hline $\begin{array}{l}\text { None } \\
0.003 \mathrm{M} \mathrm{Fe}(\text { III })\end{array}$ & $\begin{array}{l}2 \\
1\end{array}$ & $\begin{array}{l}50 \\
50\end{array}$ & $\begin{array}{l}13.5 \\
15\end{array}$ & $\begin{array}{l}86 \\
85\end{array}$ \\
\hline $0.003 \mathrm{M} \mathrm{Fe}($ III) & 2 & 50 & 3.5 & 96 \\
\hline $0.003 \mathrm{M} \mathrm{Fe}($ III) & 3 & 50 & 3.9 & 96 \\
\hline $0.006 \mathrm{M} \mathrm{Fe}($ III $)$ & 2 & 50 & 3.6 & 96 \\
\hline
\end{tabular}

* Initial solution concentration: $4.16 \mathrm{M} \mathrm{HNO}_{3}$, $0.018 \mathrm{M} \mathrm{Np}(\mathrm{V}), 0.10 \mathrm{M} \mathrm{N} \mathrm{N}_{4}$

The best data indicate 96 to $97 \%$ reduction in 2 to 3 hours at $50^{\circ} \mathrm{C}$, but uncertainties in the molar absorptivity values are great enough that the reaction may be essentially complete.

Absorption spectra (Figure 1) show that $\mathrm{Np}(\mathrm{V})$ disproportionates instantly at room temperature in $8 \mathrm{M} \mathrm{HNO}_{3}$, according to

$2 \mathrm{NpO}_{2}^{+}+4 \mathrm{H}^{+}+\mathrm{Np}^{4+}+\mathrm{NpO}_{2}^{++}+2 \mathrm{H}_{2} \mathrm{O}$

Assuming the molar absorptivities are the same in $8 \mathrm{M} \mathrm{HNO}_{3}$ as in $4 \mathrm{M} \mathrm{HNO}_{3}$, the solution contained $17 \% \mathrm{~Np}(\mathrm{~V}), 40 \% \mathrm{~Np}(\mathrm{IV})$, and 43\% Np(VI). From these data, the approximate equilibrium constant, $\mathrm{K}$, is about $10^{-6}$. The driving force for the disproportionation comes from the fourth power acid dependence on the equilibria, and the nitrate complexing of $\mathrm{Np}^{4+}$, both of which act to shift the equilibrium to the right. Reduction of $\mathrm{Np}(\mathrm{V})$ and $\mathrm{Np}(\mathrm{VI})$ in $8 \mathrm{M} \mathrm{HNO}$ took place in 30 minutes at $50^{\circ} \mathrm{C}$, without a metal ion catalyst. Experimental results are summarized in Table 5. 


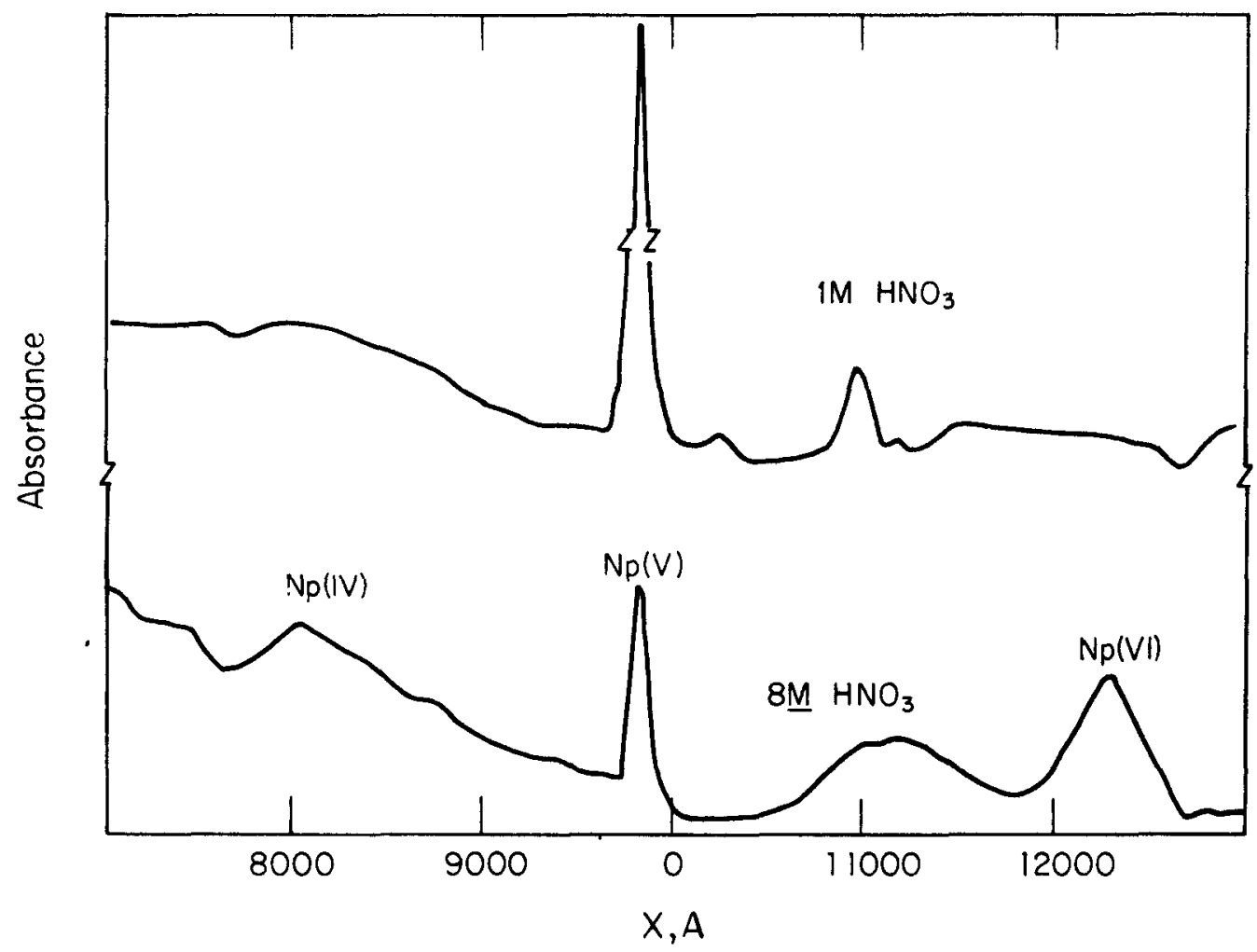

FIGURE 1. Absorption Spectra of $\mathrm{Np}(\nabla)$ in $1 \mathrm{M} \mathrm{HNO}_{3}$ and $8 \mathrm{M} \mathrm{HNO}_{3}$. 
TABLE 5

\section{$\mathrm{Np}(\mathrm{V})-\mathrm{Np}(\mathrm{VI})$ Reduction in $8 \mathrm{M} \mathrm{HNO}_{3}$ *}

$\underline{\mathrm{M}_{2} \mathrm{H}_{4} \text { Conc, }}$

Time, Temp,

$\underline{\text { hr }}$

0.10

0.10

0.10

0

0

0

0.10

$0.10 * *$

0.01

0.0033

$1 / 2$

1

1.5

$1 / 3$

${ }^{\circ} \mathrm{C}$

$\% \mathrm{~Np}$ (IV)

$\% \mathrm{~Np}(\mathrm{~V})$

$\sim 100 \quad-$

$\sim 100 \quad-$

$\sim 100 \quad-$

$40 \quad 17$

$40 \quad 17$

$40 \quad 17$

$\begin{array}{llll}2 & 50 & 40 & 17 \\ 2 & 50 & \sim 100 & -\end{array}$

$\begin{array}{lll}50 & \sim 100 \\ 50 & \sim 100\end{array}$

$\begin{array}{llll}2 & 50 & \sim 100 & - \\ 1 / 2 & 50 & 73 & 7\end{array}$

* Initial solution concentration: $7.92 \mathrm{M} \mathrm{HNO}_{3}, 0.018 \mathrm{M} \mathrm{Np}$. * $0.003 \mathrm{M} \mathrm{Fe}$ (III) added.

Assuming complete oxidation of hydrazine in the last experiment of Table 5, two moles of $\mathrm{Np}(\mathrm{V})$ [as a mixture of $\mathrm{Np}$ (IV), $\mathrm{Np}(\mathrm{V})$, and $\mathrm{Np}(\mathrm{VI})]$ were reduced per mole of hydrazine.

\section{Plutonium Reduction}

Plutonium reduction was investigated only in $8 \mathrm{M} \mathrm{HNO}_{3}$, the acid concentration for $\mathrm{Pu}$ (IV)-Np(IV) absorption for anion exchange processing. All tests were run at $50^{\circ} \mathrm{C}$, since the above results showed complete reduction of $\mathrm{Np}(\mathrm{V})$ in 30 minutes. The aim of these tests was to develop a procedure that would permit reduction of $\mathrm{Pu}(\mathrm{IV})$ to $\mathrm{Pu}(\mathrm{III})$ under the same conditions.

The results of the tests are shown in Table $6 . \quad \mathrm{Pu}(\mathrm{IV})$ was completely reduced in one hour by $0.12 \mathrm{M} \mathrm{N}_{2} \mathrm{H}_{4} \cdot \mathrm{HNO} 3$ with $0.017 \mathrm{M} \mathrm{Cu}(-$ II) as a catalyst. $\mathrm{Fe}(\mathrm{III})$ and $\mathrm{Mo}(\mathrm{VI})$ showed no catalytic effect; hydrazine alone reduced $\mathrm{Pu}($ IV) slowly, about $60 \%$ in two hours at $50^{\circ} \mathrm{C}$. 
TABLE 6

Reduction of $\mathrm{Pu}(\mathrm{IV})$ by Hydrazine in $8 \mathrm{M} \mathrm{HNO}_{3}$ at $50^{\circ} \mathrm{C} *$

\begin{tabular}{|c|c|c|}
\hline Catalyst & $\begin{array}{l}\text { Time, } \\
\mathrm{hr}\end{array}$ & $\% \mathrm{Pu}($ III $)$ \\
\hline - & - & 0 \\
\hline - & $1 / 2$ & 32 \\
\hline - & 1 & 62 \\
\hline- & 2 & 68 \\
\hline $0.0166 \mathrm{M} \mathrm{Cu}$ (II) & $1 / 2$ & 70 \\
\hline $0.0166 \mathrm{M} \mathrm{Cu}(\mathrm{II})$ & $1-1 / 2$ & 100 \\
\hline $0.0083 \mathrm{M} \mathrm{Cu}(\mathrm{II})$ & $1 / 2$ & 46 \\
\hline $0.0083 \mathrm{M} \mathrm{Cu}(\mathrm{II})$ & 1 & 77 \\
\hline $0.0083 \mathrm{M} \mathrm{Cu}(\mathrm{II})$ & $1-1 / 2$ & 100 \\
\hline $0.0083 \mathrm{M} \mathrm{Cu}(\mathrm{II})$ & 2 & 100 \\
\hline $0.0033 \mathrm{M} \mathrm{Fe}$ (III) & $1 / 2$ & 58 \\
\hline $0.0033 \mathrm{M} \mathrm{Fe}($ III $)$ & 1 & 58 \\
\hline $0.0033 \mathrm{M} \mathrm{Fe}$ (III) & 2 & 57 \\
\hline $0.004 \mathrm{M} \mathrm{Na} 2 \mathrm{MoO}_{4}$ & 2 & 58 \\
\hline
\end{tabular}

\# Initial solution concentration: $7.92 \mathrm{M} \mathrm{HNO}_{3}, 0.010 \mathrm{M} \mathrm{Pu(IV)}$

\section{DISCUSSION}

These data can be applied to a valence adjustment for the anion exchange coabsorption of ${ }^{238} \mathrm{Pu}$ and ${ }^{237} \mathrm{~Np}$. In $8 \mathrm{M} \mathrm{HNO}_{3}, 0.12 \mathrm{M}$ $\mathrm{N}_{2} \mathrm{H}_{4} \cdot \mathrm{HNO}_{3}$ at $50^{\circ} \mathrm{C}$ will reduce $\mathrm{Np}(\mathrm{V})$ completely to $\mathrm{Np}(\mathrm{IV})$, and about 30 to $35 \%$ of the $\mathrm{Pu}(\mathrm{IV})$ will reduce to $\mathrm{Pu}(\mathrm{III})$ in 30 minutes. Since the absorption of $\mathrm{Pu}(\mathrm{IV})$ by anion exchange resin shifts the $\mathrm{Pu}($ IV)-Pu(III) equilibrium rapidly, it is expected that both $\mathrm{Np}$ and $\mathrm{Pu}$ would be essentially completely absorbed by the anion resin from this solution.

Reduction by hydrazine with $\mathrm{Cu}(\mathrm{II})$ catalyst produces an $\mathrm{Np}$ (IV)-Pu(III) solution that can be the feed for an anion exchange separation of ${ }^{238} \mathrm{Pu}$ from ${ }^{237} \mathrm{~Np}$. Hydrazine reduces $\mathrm{Np}(\mathrm{V})$ to $\mathrm{Np}(\mathrm{IV})$ in 30 minutes at $50^{\circ} \mathrm{C}$ and with the addition of $0.016 \mathrm{M} \mathrm{Cu(II)}$ as a catalyst, $\mathrm{Pu}(\mathrm{IV})$ is reduced to $\mathrm{Pu}(\mathrm{III})$ in one hour. Thus, hydrazine nitrate can be used for the reductant for anion exchange. partitioning, reducing the use of FeSA to partition-washing only. Ascorbic acid use could be eliminated entirely. 
Hydrazine catalyzed by $\mathrm{Fe}$ (III) has a potential use in the reduction of $\mathrm{Np}(V)$ for solvent extraction processing with $4 \mathrm{M} \mathrm{HNO}_{3}$, again reducing the use of FeSA for feed adjustment. However, the use of FeSA in the scrub solution would still be necessary, since at ambient temperature $\left(\sim 28\right.$ to $\left.33^{\circ} \mathrm{C}\right)$, reduction by hydrazine is too slow to prevent the loss of $\mathrm{Np}(\mathrm{V})$.

The spectrophotometric study of the reduction of $\mathrm{Np}(\mathrm{V})$ in $8 \mathrm{M} \mathrm{HNO}_{3}$ at $50^{\circ} \mathrm{C}$ showed the reduction to be 3 to 4 times more rapid than reduction in $4 \mathrm{M} \mathrm{HNO}_{3}$, and two moles of $\mathrm{Np}(\mathrm{V})$ were reduced per mole of $\mathrm{N}_{2} \mathrm{H}_{4}$ oxidized. In $5 \mathrm{M} \mathrm{HClO}_{4}$ at $90^{\circ} \mathrm{C}^{6}$, one mole of $\mathrm{Np}(\mathrm{V})$ was reduced per mole of $\mathrm{N}_{2} \mathrm{H}_{4}$. However, in $8 \mathrm{M} \mathrm{HMO}_{3}$, the $\mathrm{Np}(\mathrm{V})$ added very rapidly disproportionates to a mixture of $40 \% \mathrm{~Np}$ (IV), $17 \% \mathrm{~Np}(\mathrm{~V})$, and $43 \% \mathrm{~Np}(\mathrm{VI})$, and the reduction of $\mathrm{Np}(\mathrm{V})-\mathrm{Np}(\mathrm{VI})$ can take place by three different routes: (a) the one-electron reduction of $\mathrm{Np}(\mathrm{VI})$ to $\mathrm{Np}(\mathrm{V})$, followed by a one-electron reduction of $\mathrm{Np}(\mathrm{V})$ to $\mathrm{Np}(\mathrm{IV})$, as (acid hydrogens omitted)

(1) $\mathrm{Np}(\mathrm{VI})+\mathrm{N}_{2} \mathrm{H}_{4}+\mathrm{Np}(\mathrm{V})+\mathrm{NH}_{4}^{+}+1 / 2 \mathrm{~N}_{2}$

(2) $\mathrm{Np}(\mathrm{V})+\mathrm{N}_{2} \mathrm{H}_{4}+\mathrm{Np}(\mathrm{IV})+\mathrm{NH}_{4}^{+}+1 / 2 \mathrm{~N}_{2}$

or (b) reduction of $\mathrm{Np}(\mathrm{VI})$ to $\mathrm{Np}(\mathrm{V})$, as in reaction (1), followed by disproportionation of $\mathrm{Np}(\mathrm{V})$ to $\mathrm{Np}(\mathrm{VI})$ and $\mathrm{Np}(\mathrm{V})(\mathrm{p} .8)$; or (c) a two-electron reduction of $\mathrm{Np}(\mathrm{VI})$ to $\mathrm{Np}(\mathrm{IV})$,

$$
\mathrm{Np}(\mathrm{VI})+\mathrm{N}_{2} \mathrm{H}_{4}+\mathrm{Np}(\mathrm{IV})+1 / 2 \mathrm{NH}_{4}{ }^{+}+1 / 2 \mathrm{HN}_{3}+3 / 2 \mathrm{H}^{+}
$$

with the disproportionation of $\mathrm{Np}(\mathrm{V})$ producing more $\mathrm{Np}(\mathrm{VI})$ as the reaction continues. Reaction sequences (a) and (b) reduce one mole of the "average" $\mathrm{Np}(\mathrm{V})$ per mole of hydrazine; reaction sequence (c) reduces two moles of "average" $\mathrm{Np}(V)$ per mole of hydrazine. From the experimental stoichiometry, it is inferred that the major part of the reduction of $\mathrm{Np}(\mathrm{V})$ in $8 \mathrm{M} \mathrm{HNO}_{3}$ actually proceeds via reaction sequence (c), the direct two-electron reduction of $\mathrm{Np}(\mathrm{VI})$ to $\mathrm{Np}$ (IV) by hydrazine. Further evidence is that reaction (2) in $1.5 \mathrm{M}$ or $4 \mathrm{M} \mathrm{HNO}_{3}$ is slower, even with a metal catalyst, than the reaction in $8 \mathrm{M} \mathrm{HNO} \mathrm{H}_{3}$, indicating that the reaction in $8 \mathrm{M} \mathrm{HNO}$ takes place through a different mechanism.

The reduction of $\mathrm{Pu}$ (IV) by hydrazine has been previously studied in $1.9 \mathrm{M} \mathrm{HNO}_{3}$ and $50^{\circ} \mathrm{C} .^{7}$ The reduction had a half-time of about 40 minutes, which agreed with a 40- to 50-minute halftime for the uncatalyzed reduction in this work. In later work, 8 it was found that $4 \times 10^{-3} \mathrm{M} M(\mathrm{VI})$ as a catalyst increased the reaction rate by a factor of four. An unavailable Russian treatise ${ }^{9}$ is quoted on catalys is by $\mathrm{Fe}$ (III), probably in $\sim 2 \mathrm{MNO}_{3}$. This work showed no appreciable catalysis by either Mo(VI) or $\mathrm{Fe}$ (III) in $8 \mathrm{M} \mathrm{HNO}_{3}$. $\mathrm{Pu}\left(\right.$ IV) is present in $8 \mathrm{M} \mathrm{HNO}_{3}$ as a nitrate complex ion, so the difference in the behavior of the reaction is not unexpected. 
In conclusion, this work has shown several procedures for reduction of $\mathrm{Np}(\mathrm{V})$ and $\mathrm{Pu}(\mathrm{IV})$ that appear to be applicable to separations processes. Confirmatory anion exchange and solvent extraction experiments on process solutions will be conducted. If successful, plant application of these techniques will be recommended. 
1. H.A. Friedman and L.M. Toth. J. Inorg. Nucl. Chem. 42, 1347 $(1980)$.

2. E. K. Dukes and W. E. Shuler. Spectrophotometric Determination of Mixtures of Neptunium( IV) and Neptunium(V) in Nitric Acid Solutions. USAEC Report DP-543, E. I. du Pont de Nemours \& Co., Savannah River Laboratory, Aiken, SC (1960).

3. D. Cohen. J. Inorg. Nucl. Chem. 18, 211 (1961).

4. R. E. Kirk and A. W. Browne. J. Am. Chem. Soc. 50, 337 (1928).

5. W. C. Bray and E. J. Cuy. J. Am. Chem. Soc. 46, 858 (924); 46, 1786 (1924).

6. V. S. Koltunov and M. F. Tikhonov. Radiokhimiya 15, 789 (1973); 17560 (1975).

7. V. S. Koltunov and G. I. Zhuravieva. Radiokhimiya 16, 84 (1974).

8. V. S. Koltunov and G. I. Zhuravieva. Radiokhimiya 22, 57 (1980).

9. V. S. Koltunov. Reaction Kinetics of the Actinides (in Russian) p. 228, Atomizdat: Moscow, USSR (1974). 